\title{
The Future Prospects of E-learning: The View of the Apex Body of Higher Educational Institutions (HEIs) in Sri Lanka
}

\author{
*Mohamed Hussain Thowfeek ${ }^{1}$, Azizah Jaafar² \\ ${ }^{1}$ South Eastern University of Sri Lanka, Oluvil, Sri Lanka \\ ${ }^{2}$ Universiti Kebangsaan Malaysia, Bangi, Selangor, Malaysia \\ *thowfeek@seu.ac.lk
}

\begin{abstract}
The use of Information and Communication Technology (ICT) in higher education has created totally a new environment which is fundamentally different from the traditional learning methods. The objectives of the study were to get the view of the University Grants Commission (UGC) about e-learning system and to investigate the possibilities of formalizing its implementation in the universities in future. As it is an exploratory study, the case study method was deemed appropriate. The result of the study shows that the UGC is favorable on the implementation of a campus-wide e-learning system in all universities. Though there is no formal policy on the embarkation of e-learning mode so far, it encourages the universities to adopt the system. This paper has also highlighted the possible areas for the early implementation of the e-learning mode and other requirements that should be considered for the future adoption of e-learning system.
\end{abstract}

Key words: E-learning, dual mode, higher education, adoption, ICT.

\section{Introduction}

Information and Communication Technology (ICT) plays a crucial role almost in all organizations and businesses these days (Zhang \& Aikman, 2007) and its influence in the educational sector is also inevitable. The use of ICT in education has created totally a new environment which is fundamentally different from the traditional face to face learning methods. E-learning, the term coined to describe the new teaching and learning environment, encompasses all the forms of electronic facilitation to enrich the teaching and learning processes. If any teaching and learning activity is supported by ICT, it can be labelled as e-learning (Sambrook, 2003).

The e-learning system is adopted by the higher educational institutions with the hope of eliminating the barriers and problems that exist in the traditional methods. The main reasons for a wider acceptance of this method can be credited to its advantages such as accessibility, availability and flexibility. This method provides opportunities to those students who are having time restriction, physical barrier and social or economic constraints to attend on-campus programme (Appana, 2008; Vaughan, 2007) and students also consider this method more convenient to work and learn, because it gives them more independent learning experience. They can access the learning material at any time and learn from anywhere in the world. The diffusion of ICT into education sector enabled the knowledge domain to grow more vividly. Mahdizadeh, Biemans, and Mulder (2008) noted that the e-learning environment also enables teachers to provide students with different representation of knowledge and to enhance interaction between teachers and students and among students themselves. In addition, the e-learning method enhances the quality of teaching and learning process by providing effective ways that were not possible before (Dawes, 2001).

The technological innovation in the education presents more advantages which encourage the higher educational institutions to adopt e-learning system. It can be observed that there are many universities around the world nowadays expanding their investment in ICT (Cheung \& Huang, 2005) in order to improve the quality of learning (Cancannon, Flynn, \& Campbell, 2005). It is also noted that the educational administrators who seek to turn their institutions into high-tech learning institutions pressurize their instructors to incorporate technology into the instructional activities, and students who are persistent that the technology be used in their programmes also give pressure to adopt e-learning system (Bennett \& Bennett, 2003). Though the technology revolutionized the way of teaching and learning, a number of studies reported the barriers and challenging in using e-learning system. Lack of teacher time, limited access and 
high cost of equipment, lack of vision or rationale for technology use, lack of teacher training and support, and current assessment practices (Mahdizadeh, Biemans, \& Mulder, 2008); lack of confidence, lack of competence and lack of access to resources (Bingimlas, 2009) internal or external, legal and/or politic barriers might influence the applicability of e-learning (Aydin, \&Tasci, 2005); and infrastructure and funding OECD (2005) are major identified barriers and challenges in different contexts of using e-learning system. These barriers are neither always threat to nor exist in all the educational institutions. However, the individual organization has to give prior considerations to those possible problems when implementing such a system.

\section{Literature Review}

ICT Development in Sri Lanka: The Government of Sri Lanka has introduced several ICT projects with one of the objectives of increasing the computer literacy rate. According to the Department of Census and Statistics, Sri Lanka the computer literacy rate has been increased from 16.1\% reported in 2006/07 to $20.3 \%$ in 2009. This result shows that the plan of the Government to improve ICT education has been well executed. The Government of Sri Lanka has formulated the National Policy on Information Technology in School Education (NPITSE) in 2001. The vision of NPITSE is to create a new generation empowered with ICT and facilitate the planning, implementation and sustenance of Information Technology education in schools to enhance students' learning and quality of teaching. Since the formulation of the NPITSE, the Government has initiated several programmes under four strategic themes namely, curriculum development, human resources development, physical infrastructure development and support initiatives development. In accordance with the Government policy, the Ministry of Education (MOE) has introduced ICT education in the secondary school curriculum in 2002 and set the target of offering ICT as subject for grade 3 to 13 starting from the year 2013 .

In the opinion of Rainford (n.d), the e-government strategy in Sri Lanka is one of the most comprehensive models among Asian countries. The strategy that aims to significantly impact all sectors of the economy and society is expected to help the nation take a major leap forward in economic and development activities. His Excellency President, Mahinda Rajapaksa, has developed a strategic plan called 'MahindaChintana' the vision for a new Sri Lankawhich places greater emphasis on rural development. ICT has been incorporated as an integral and increasingly prominent part into thesedevelopment plans.

The project of the Government like Distance Education Modernisation Project (DEMP) and e-Sri Lanka are apparently a steppingstone towards the implementation of ICT based education mode in Sri Lankan education system. The MOHE has launched DEMP in December 2003 under the sponsorship of Asian Development Bank with the aim of integrating ICT to deliver education programmes and to eliminate the conventional barrier associated with the delivery of the programmes. Universities, professional associations, private and public sector education institutions have become partners under this project.Under this project a program called NODES (National Online Distance Education Service) started to develop online distance learning institutions and to deliver online distance learning throughout the country. A few partner universities offer limited programmes ranging from certificate to master degree under this project.E-Sri Lanka is another huge project that has been funded by the World Bank, the Government of Sri Lanka, The Swedish International Development Corporation Authority (SIDA), the Export and Import Bank of Korea and Japan Social Development Fund. The Information and Communication Technology Agency of Sri Lanka (ICTA) has been implementing this project since 2004. The objective of the project is to utilize ICT to develop the economy of Sri Lanka, eradicate poverty and improve the quality of life of the people and this project consists of six components such as ICT Policy, Leadership and Institutional Development Programme, The Information Infrastructure; Re-engineering Government; ICT Human Resource Development; ICT Investment and Private Sector Development; and e-Society (Hanna, 2008).

While the government of Sri Lanka has been successful at implementing all these projects to develop the country's ICT education, the e-learning system, the new paradigm of teaching and learning enabled by the ICT has not yet been fully adopted or utilized to improve the educational activities of the all universities in Sri Lanka. It could be noted that many universities around the world are heavily investing in ICT based education system realizing the benefits that offers. It would enhance the quality of teaching and learning process (Dawes, 2001; and Cancannon, Flynn, \& Campbell, 2005) and be an alternative solution for the problems 
encountered in the traditional face to face teaching method (Eynon, 2008). A few Sri Lankan universities have introduced the e-learning mode for certain programmes at some of the departments or faculties. If all the universities can introduce a campus-wide e-learning system, the major problem in the tertiary education system can be solved.

Tertiary Education: The importance of the value of education is well recognized in the Sri Lankan education system and it has been given a higher priority in order to provide the younger generation with skills, knowledge and competency to face the global challenges of the new era. The Government of Sri Lanka offers free education from primary to tertiary level which helped to achieve a high literacy rate of $92 \%$ among the developing countries. The Ministry of Education (MEO) has made remarkable reforms in its primary and secondary education system with the objectives of extending educational opportunities and improving the quality of education and achieved successes with the concluding phase in 2003 (MOE, 2004). But, as far as the tertiary education is concerned, there is a huge restriction in extending its educational facilities to the all qualified of students. This is because of the limited resources and infrastructure facilities at universities. There are only 15 universities in Sri Lanka and admissions to the undergraduates programs at these universities are based solely on the G.C.E (A/L) examination and the Z-score. The university Grants Commission (UGC) allots students to the universities based on the availability of courses, preference of students, scored gained, accessibility issues etc. The statistic in the book of Admission to Undergraduate Courses of the Universities in Sri Lanka: Academic Year 2009/2010 shows that only 15.56\% of students have been admitted to the universities. This is the normal average percentage of every year intake. Nanayakkara, Wijesuriya, and Damayanthi (2006) stated that a limited number of admissions are given to the A/L qualified students to enroll for the degree programs due to non-availability of places in the universities.

Majority of the students who are qualified to pursue a degree programme but unsuccessful in securing admissions to the internal degree programs due to the unavailability of places miss the educational opportunities, even though that could be obtained in different modes or from different sources like the Open Universities of Sri Lanka (OUSL). One of the major reasons identified is that the lower level of awareness among the youth on the distance education mode and the courses offered by the Open University of Sri Lanka (OUSL) (Nanayakkara, Wijesuriya, \& Damayanthi, 2006). If the university can either increase its internal admission or introduce e-learning mode of teaching, hopefully a vast number of students will be benefited. Bourlova \& Bullen (2005) ascertained that if e-learning mode is implemented in universities, it can provide flexibility in scheduling courses and improve the use of limited resources (ex: classrooms, laboratories etc.). Eynon (2008) also suggests that the adoption of e-learning can solve many problems faced by universities and it would increase efficiency and flexibility by enabling universities to embrace a greater number of students regardless of their demographical and geographical restrictions and enhancing universities global competitiveness. But due to lack of IT facilities and resources in universities, there is still a lower level of technological diffusion into the teaching and learning process in the Sri Lankan Universities.

\section{Methodology}

Qualitative approach has been adapted for the purpose of this study. In a research setting where a smaller but focused sample is considered for the study, the qualitative approached is deemed to be appropriate and this approach is also preferred when the researcher wants to investigate 'why' and 'how' of decision making (Denzin\& Lincoln, 2005; Cresswell, 2003).

The UGC, the apex body of the university system in Sri Lanka, regulates the educational and administrative affairs of the higher educational institutions (HEIs). The main functions of the UGC are planning and coordination of university education, allocation of funds to Higher Educational Institutions (HEIs), maintenance of academic standards, regulation of the administration of HEIs and regulation of admission of students to HEIs. This study has been undertaken with the following objectives:

a. To get the view of the UGC about e-learning implementation in all Sri Lanka universities and

b. To investigate the possibilities/plans/policies of formalizing e-learning implementation in the future 
In order to conduct interviews, prior appointment from the chairman of the UGC was obtained. Five successful interviews were conducted of which four of them are executive staff in top of the hierarchy and one from the Division of Management Information Systems.

\section{Discussion of the Findings}

The advent of the Internet and the World Wide Web (www) has broadened the scope of education. The new teaching and learning method termed e-learning is considered as a promising instructional mode and that has well been received especially in the developed world and they are reaping the benefits of it.

This study was undertaken to know the view of the UGC about the implementation of a full-fledge e-learning system in the higher educational institutions in Sri Lanka. Though the UGC is the apex body, it only regulates the educational and administrative affairs of the higher educational institutions and the decision over introducing any reforms in the university educational system is taken at the top level of Ministry of Higher Education (MOHE). Hence, the role of the Government in the process of implementing such a system is felt very important. The Government has already initiated some huge programmes like DEMP and e-Sri Lanka. The programme called NODE (National Online Distance Education Service) under DEMP started to deliver online distance learning throughout the country. Under this e-Sri Lanka project, the Government setup knowledge centers called 'Nenasalas' at villages in order to leverage information and communication technology to the mass. There are different types of 'Nenasalas', distance and e-learning centers is one of them. This initiation indicates us that the Government may also bring amendment in the higher educational system in order to adopt ICT based teaching and learning systemin near future. There are 15 public universities in Sri Lanka and these universities offer free education, so the Government involvement to make reforms in the university system is necessary. As Shraim and Khlaif (2010) identified, the political support is also necessary to facilitate changes like introducing e-learning approach. The UGC would be in a better position to draft a policy and other related circulars to introduce campus wide e-learning system if it gets instructions from the higher educationministry. In a study done to know the perception of instructors over the adoption of e-learning, Thowfeek and Hussin (2008) identified that there would a wider acceptance of elearning system by the instructors as well as institutions if it is mandatory.Therefore mandatory instruction from the top level authority is expected to adopt the system in the campus.

The interviewees are of the opinion that the e-learning system would definitely bring enormous benefits to the local educational institutions and students. If an educational institutional in a country is reluctant to adopt the new teaching and learning method enabled by the ICT facilities, that institution is isolated from advancing world and losing the greater opportunities to prosper in the field. Although the need for an urgent action to adopt e-learning has been realized, how and to what extend the e-learning program could be implemented in the Sri Lanka higher educational institutions has not yet been explored in detail at a corporate level. They also acknowledged that there are a number of foreign e-learning programs are intruding into our local educational sector but it cannot be ignored nor avoided. It is also understood that as Bates (2001) reported, it may present threat to the national educational institutions, culture and language. Therefore, it is important to consider the requirements of the country and the implementing institutions in the process of developing and implementing an e-learning program.

The explicit fact brought up for the discussion with the interviewees is the number of students being selected to universities. As we have discussed in the background of the study, every year a very limited number of students are given admission to the universities. This is because of non-availability of places for the degree programmes in the universities (Nanayakkara, Wijesuriya, \& Damayanthi, 2006). Lack of resources and infrastructure facilities are the main reasons for the limited number of admission. Therefore the possibility of increasing the number of admission was raised and everyone participated in the interview expressed their personal view that e-learning would be one of the alternative ways to resolve the current issue. Again, as there is no formal decision or policy within the framework of higher educational system to introduce the elearning method in order to increase the number of internal students, the individual university can take any measures to increase number of external degree students by which it can extend its educational facilities to many students who are not given opportunity to enroll for internal programs. Then the external degree program can be converted into e-learning mode or those universities can get help from the project NODES to 
offer their external degree through online distance education. Most of the interviewees preferred a 'dual mode' of education system that could be possibly introduced to increase the intake for internal degree programmes. For an example two years of face to face learning and two years of online learning method can be mixed for a four year degree programmes. Again this is the personal opinion of the interviewees and there is no a constituent element to make sure such implementation would be initiated shortly.

University is an autonomous body that has freedom of making any decisions provided that it complies with governing rules, regulations, circulars and policy of the UGC. Therefore universities can inaugurate e-learning mode in order to make use of ICT to enhance their teaching and learning processes of the internal degree programmes and it also can convert external degree programs as discussed earlier to the e-learning mode. The UGC has been continually supporting all the universities to upgrade their IT facilities. The UGC funds and the other project funds like IRQUE (improving relevance and quality of undergraduate education) were made available to do this. In the opinion of the interviewees that the majority of the universities are capable of implementing such system, but a few universities located in the rural areas are in needs of improving its IT infrastructure, Internet connection and so on. However it is questionable about the position of the students. Do they have enough facilities at home to access the e-learning resources?

The lecturers' readiness to adopt the e-learning system is another challenging area discussed with interviewees. University lecturers are hesitant to make use of technology for their teaching activities because of lacking knowledge, skill and the negative attitudes towards technology (Haynes et al., 2004). Prior experience of using e-learning or willingness to learn to e-learning system is important. The culture to welcome new thing that are beneficial to the society should be fostered. Training program has been identified as one of the preliminary arrangements before adopting the system. In the review of literatures, Bingimlas (2009) identified that ICT resources, effective professional development, sufficient time and technical support are needed to integrate technology to teaching. Further it was discussed that the instructors' opinion about the e-learning should be obtained at the first instance before making arrangement to implement the system. It will help the institution to eliminate the wrong perception about e-learning. Lecturer commitment is vital for the success of e-learning adoption.

The issue of the quality of education offered through e-learning method is widely voiced. The quality is utmost element that ensures the successful implementation of educational programmes. But it is the toughest part to make sure that the programmes offered through e-learning mode meet requirements of quality standards. Because it is not just a technology to measure the quality but a technology based instructional delivery that requires developing an appropriate assessment and evaluation method (Mandinach, 2005). The interviewees are more concerned about this issue and afraid of inferior quality of program that would be produce by process of teaching and learning in the e-learning method. It is the responsibility of each university that prefers to implement e-learning system in future should take care of this criticism and it should also eliminate the misperception about the quality issue in e-learning system in order to attract more students.

\section{Conclusion}

This study has elucidated the current situation of ICT implementation in the country and its future impact on the higher education. The Government has been taking appropriate measures to improve the computer literacy rate and ICT education. The projects like Distance Education Modernisation Project (DEMP) and e-Sri Lanka have been well executed and showing good results.

The University Grants Commission (UGC) favours the adoption of e-learning system and believes that it would solve some of the problems in traditional face to face teaching method.As there is no any policy decision so far with the regard to the implementation of e-learning, the UGC is not in a position to give instructions to the universities. The UGC performs its duty on the directions of Ministry of Higher education (MOHE); therefore it expects instructions and guidelines for implementing any reforms. However UGC allocates funds for upgrading the IT facilities and encourages incorporating the ICT into the university education. It was noted that majority of the university is capable of implementing the e-learning system but a few universities located in the rural areas are in needs of improving its IT infrastructure, Internet connection 
and so on.The capable university can either launch e-learning system to enhance the internal degree programmes or introduce e-learning system to the existing external degree programme. The number of admission to the internal degree programmes can be increased if the universities can at least introduce the dual mode of teaching. Again it is just an opinion of the interviewees at the moment but there would be some possibility for working on the issue in future.

The instructors' readiness and their opinion on the adoption of e-learning should be studiedin detail before embarking on the system. Trainingand technical support need to be providedto the instructors to facilitate the e-learning implementation. A proper mechanism to assess the quality of the programs that could be offered through e-learning mode should be in place if the universities want to embark on e-learning adoption. Overall findings indicate that the UGC is very much favourable on the adoption of e-learning and having realized the urgency of introducing the system, the UGC has been facilitating all the universities to procure necessary computers and other equipment. But it has not issued any mandatory instructions to adopt such system as there is no any policy decision so far. However it is recommended that the UGC should persuade the capable universities to adopt the e-learning system as early as possible.

\section{References}

Appana, S. (2008). A Review of Benefits and Limitations of Online Learning in the Context of the Student, the Instructor and the Tenured Faculty. International Journal on E-Learning, 7(1), 5-22.

Aydin, C. H. \& Tasci, D. (2005). Measuring Readiness for e-Learning: Reflections from an Emerging Country. Educational Technology \& Society, 8(4), 244-257.

Bates, T. (2001). International Distance Education: Cultural and Ethical Issues. Distance Education, 22(1), 122136.

Bennett, J. \& Bennett, L. (2003). A Review of Factors that Influence the Diffusion of Innovation When Structuring a Faculty Training Program. The Internet and Higher Education, 6, 53-63.

Bingimlas, K. A. (2009). Barriers to the Successful Integration of ICT in Teaching and Learning Environments: A Review of the Literature. Eurasia Journal of Mathematics, Science \& Technology Education, 5(3), 235-245.

Bourlova, T. \& Bullen, M. (2005). The Impact of E-learning on the Use of Campus Instructional Space.In R.W.H. Lau et al. (Eds.): ICWL 2005 (397-405). Berlin, Heidelberg: Springer-Verlag Berlin Heidelberg.

Cancannon, F., Flynn, A. \& Campbell, M. (2005). What Campus-based Students Think about the Quality and Benefits of e-learning? British Journal of Educational Technology, 36(3), 501-512.

Cheung, W. \& Huang, W. (2005). Proposing a Framework to Assess Internet Usage in University Education: An Empirical Investigation from a Student's Perspective. British Journal of Educational Technology, 36(2), 237-253.

Cresswell, J. W. (2003). Research Design: Qualitative, Quantitative, and Mixed Methods Approaches (2nd Ed.). Thousand Oaks, CA: Sage.

Dawes, L. (2001). What Stops Teachers Using New Technology? In M. Leask (Ed.), Issues in Teaching Using ICT (61-79). London: Routledge.

Denzin, N. K. \& Lincoln, Y. S (Ed.). (2005). The Sage Handbook of Qualitative Research (3rd ed.). Thousand Oaks, CA: Sage.

Eynon, R. (2008). The U of the World Wide Web in Learning and Teaching in Higher Education: Reality and Rhetoric. Innovations in Education and Teaching International, 45(5), 15-23.

Hanna, N. G. (2008). Transforming Government and Empowering Communities: The Sri Lankan Experience with e-Development. Washington, D.C: The World Bank.

Haynes, P., Saintas, P., Stanier, S., Palmer, H., Thomas, N., Reast, G., Barlow, J. \& Maillarder, F. (2004). Responding to Technological Change: IT skill and the Academic Teaching Profession. Active Learning in Higher Education, 5(2), 152-165.

Mahdizadeh, H., Biemans, H. \& Mulder, M. (2008). Determining Factors of the Use of E-learning Environments by University Teachers.Computers \& Education, 51, 142-154.

Mandinach, E. B. (2005). The Development of Effective Evaluation Methods for E-Learning: A Concept Paper and Action Plan. Teachers College Record, 107(8), 1814-1836. 
MOE. (2004). TheDevelopment of Education, National Report. Retrieved December 12, 2010, from http://www.ibe.unesco.org/International/ICE47/English/Natreps/reports/srilanka.pdf.

Nanayakkara, G. L. S., Wijesuriya.G. E. \& Damayanthi, P. V. (2006). Study on the Characteristics of G.C.E (A/L) Qualified Youth Not Currently Studying. Retrieved December 18, 2010, from http://www.nodes.lk/rp.html.

Rainford, S. (n.d). E-Sri Lanka: An Integrated Approach to E-Government Case Study. Retrieved December 27, 2010, from http://www.apdip.net/projects/e-government/capblg/casestudies/SriLankaRainford.pdf.

Sambrook, S. (2003). E-learning in Small Organizations. Education + Training, 45(8/9), 506-516.

Shraim, K. \& Khlaif, Z. (2010). An E-learning Approach to Secondary Education in Palestine: Opportunities and Challenges. Information Technology for Development, 16(3), 159-173.

Thowfeek, M. H., \& Hussin, H. (2008). Instructors' Perspective on E-Learning Adoption in Sri Lanka: A Preliminary Investigation. Communications of the IBIMA, 6, 124-129.

Vaughan, N. (2007). Perspectives on Blended Learning in Higher Education. International Journal on ELearning, 6(1), 81-94.

Zhang, P., \& Aikman, S. (2007). Attitudes in ICT Acceptance and Use.In J. Jacko (Ed.), Human-Computer Interaction (1021-1130). Berlin, Heidelberg: Springer-Verlag Berlin Heidelberg. 